Biol. Stud. 2021: 15(1); 49-60 • DOI: https://doi.org/10.30970/sbi.1501.647

www.http://publications.Inu.edu.ua/journals/index.php/biology

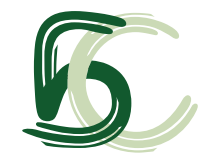

UDC: 615.371:616-006-092.18

\title{
EXPERIMENTAL MODEL AND APPROACHES TO INVESTIGATION OF THE ACQUIRED RESISTANCE TO TUMOR TRANSPLANTATION IN MICE
}

\author{
M. D. Lootsik®, R. S. Stoika®* \\ Institute of Cell Biology, NAS of Ukraine, 14-16 Drahomanov St., Lviv 79005, Ukraine \\ *Corresponding author e-mail: stoika@cellbiol.Iviv.ua
}

Lootsik M.D., Stoika R.S. Experimental model and approaches to investigation of the acquired resistance to tumor transplantation in mice. Studia Biologica, 2021: 15(1); 49-60 • DOI: https:// doi.org/10.30970/sbi.1501.647

Introduction. An acquired resistance to experimental tumors was detected in animals that recovered from a primary transplanted tumor due to treatment or spontaneously, and demonstrated intolerance to a renewal tumor inoculation. This phenomenon is much less frequently observed, although it is of great scientific interest and medical significance. Here, we have addressed the expression of the resistance phenomenon in a model tumor in mice - Nemeth-Kelner lymphoma (NK/Ly).

The aim of our study was to elaborate a reproducible method for induction of resistance to transplantation of lymphoma NK/Ly in mice and to investigate the mechanisms of its development.

Methods and Results. Three schemes for induction of resistance were tested. The first one included treatment of tumor-bearing mice with vinblastine and, thereafter, reconvalescent animals were checked for the development of resistance expressed as a complete suppression of tumor growth after re-inoculation of tumor cells. Mice were inoculated intraperitoneally with NK/Ly ascitic cells and then subjected to 2-4 intraperitoneal injections of vinblastine at a dose of $1 \mu \mathrm{g} / \mathrm{g}$ of body weight. The recovered mice were re-inoculated with tumor cells and the absence of tumor growth was considered as resistance development. The disadvantage of this approach is that less than $5 \%$ of mice achieve a long lasting recovery due to the treatment. The second scheme included the immunization of mice with intraperitoneal injection of the minimal number of viable tumor cells that do not cause tumor growth, but initiate the immune response. However, this approach was not effective, since there was no reliable number of cells corresponding to these demands. The minimal number of $15 \times 10^{3}$ injected cells per mouse caused a retarded but still progressive tumor growth. In the third scheme, the immunization of

(C) 2021 M. D. Lootsik et al.; Published by the Ivan Franko National University of Lviv on behalf of Біологічні Студії / Studia Biologica. This is an Open Access article distributed under the terms of the Creative Commons Attribution License (http://www.budapestopenaccessinitiative.org and Creative Commons Attribution 4.0 License), which permits unrestricted reuse, distribution, and reproduction in any medium, provided the original work is properly cited.

ISSN 1996-4536 (print) • ISSN 2311-0783 (on-line) • Біологічні Студії / Studia Biologica • 2021 • Том 15 / № 1 • С. 49-60 
mice was conducted by the intraperitoneal injections of NK/Ly cells permeabilized with saponin. It should be noted that treatment with saponin leads to cell death with a minimal damage to cell morphology. The scheme of immunization with permeabilized NK/Ly cells appeared to be simple and effective. It provided a reproducible resistance to transplanted tumor and might be used as a model in studies of the mechanisms of this phenomenon. Cytological investigation of tumor and immunocompetent cells in ascites of control and of tumor-resistant mice was conducted. As revealed, the number of lymphocytes in ascites of tumor-resistant mice was about 4 times higher than such amount in the control (non-resistant) mice. A destruction of tumor cells by the adherent mononuclears was observed.

Conclusions. The method of induction of resistance to transplantation of experimental tumor NK/Ly by immunization of mice with tumor cells permeabilized with saponin is described. The intraperitoneal inoculation of tumor cells to the tumor-resistant mice caused the marked increase of the mononuclear leukocytes population in the peritoneal fluid, which showed a harmful effect upon tumor cells. Thus, the induction of resistance to transplantation of NK/Ly lymphoma in mice might be provided mainly via the mechanisms of cell immunity, in particular, by the appearance of cytotoxic lymphocytes specific to distinct tumor cells.

Keywords: lymphoma NK/Ly, mice, tumor transplantation, resistance

\section{INTRODUCTION}

There wee many attempts to program immune cells for specific recognition and destruction of the pathological, primarily tumor cells. The immunologists James Allison and Tasuku Honjo who worked in that field were awarded the Nobel Prize in Physiology and Medicine in 2018. Their approach was based on enhancing the activity of the human immune system to overcome cancer without the use of radiotherapy or chemotherapy [20]. The above noted scientists have invented effective methods for suppression of the protective response of tumor cells to the action of immune cells. James Allison et al. found that blocking of the CTLA-4 (cytotoxic lymphocytes A-4) protein involved in the functioning of the immune system in animals with malignant tumors leads to the activation of the body's antitumor response and tumor regression. Tasuku Honjo identified the PD-1 receptor (Programmed Cell Death Protein-1) on the surface of lymphocytes and showed that its activation leads to inhibition of the action of lymphocytes on tumor cells. Therefore, blocking PD-1 enhances the antitumor activity of the immune system [15]. Studies related to the CTLA-4 protein and the PD-1 receptor are among the most relevant to the treatment of cancer and therefore, many recent reviews in leading biomedical journals have been published [6, 14].

Other mechanisms have been proposed to be used for stimulation of the immune system toward tumor cells, and the CAR-T system is the best known to target immune cells to leukemia cells [4]. For this reason, the T lymphocytes of a cancer patient were isolated and genetically reprogrammed in vitro to find and destroy leukemic cells. Then, the modified lymphocytes were returned to the patient's body, where their number increased with each contact with cancer cells. Taking into account a wide distribution of the MR1 and a small difference in its content between the individuals, one can expect

ISSN 1996-4536 (print) • ISSN 2311-0783 (on-line) • Біологічні Студії / Studia Biologica • 2021 • Том 15 / № 1 • C. 49-60 
the creation of a universal antitumor immunotherapy. Considering the appearance of intolerance to experimental tumors, it is known that animals with a transplanted model tumor, which recovered after the successful treatment, became resistant to a renewal inoculation of this tumor $[1,8,9]$. The causes of this phenomenon are poorly investigated, although they are of great interest and medical significance. There is reason to believe that this phenomenon is based on the peculiarities of the functioning of the immune system in individual organisms [7, 19]. Here, we have addressed expression of the resistance phenomenon in a model tumor of mice - lymphoma NK/Ly.

The aim of our study was to elaborate a reproducible method for induction of resistance to transplantation of lymphoma NK/Ly in mice and to investigate the mechanisms of its development paying attention to the role of cellular immune response in this process.

\section{MATERIALS AND METHODS}

Experiments were conducted on murine experimental tumor lymphoma NK/Ly, obtained from the collection of tumor strains of the R.E. Kavetsky Institute of Experimental Pathology, Oncology and Radiobiology, National Academy of Sciences of Ukraine, Kyiv (Ukraine). Animals were housed with a free access to food and water in accordance with the General Ethical Principles of Experiments on Animals (Ukraine, 2001), which are consistent with the provisions of The European Convention for the Protection of Vertebrate Animals Used for Experimental and Other Scientific Purposes (Strassburg, 1986). The study was conducted with the approval of the Bio-Ethics Commission at the Institute of Cell Biology, NAS of Ukraine (Protocol \# 2, February 18, 2021).

Ascites forms of NK/Ly was passed in C57BI mice by intraperitoneal inoculation of $0.5-1.0 \times 10^{6}$ tumor cells. The applied number of NK/Ly cells was 10-20 times lower than usually recommended for this tumor $[12,17,18]$. This is caused by a continuous passage of tumor NK/Ly in vivo for a long time (10 years) which led to a substantial enhancement of its malignancy as compared with the parental strain. Nevertheless, the applied number of NK/Ly cells was quite sufficient for a "normal" growth of tumor, besides, a lower dose of transplanted cells is favorable to experimental chemotherapy of tumor.

The growth of tumors was monitored by weighting the animals daily or on even days. Ascitic cells for transplantation were taken on the 10-13 days of lymphoma NK/Ly. Evacuation of ascitic fluid (drainage) was performed under the light ether narcosis.

Treatment of mice was performed by intraperinoneal injections of vinblastine sulfate [3]. The solution for injections was prepared as follows. $1 \mathrm{mg}$ of vinblastine sulfate powder was suspended in $0.1 \mathrm{~mL}$ of ethanol and $0.1 \mathrm{~mL}$ of sterile water was added to the suspension. A rapid dissolution occurs and in this way a stock solution of vinblastine with concentration $5 \mathrm{mg} / \mathrm{mL}$ in $50 \%$ ethanol was obtained. It can be stored at $4{ }^{\circ} \mathrm{C}$ no longer than 7 days. The solution for injection was prepared by introducing $5 \mu$ of stock vinblastine to $0.5 \mathrm{~mL}$ of sterile saline and was injected to one mouse. More solution can be prepared for treatment of several mice according to the indicated proportion and it must be used in several hours.

Cytomorphological investigations of cell population in ascitic fluid of control mice or in peritoneal fluid of tumor-resistant mice were performed. Smears were stained with azure A-eosin dye by Romanovsky-Giemsa method in R. Lilly modification [11] and the

ISSN 1996-4536 (print) • ISSN 2311-0783 (on-line) • Біологічні Студії / Studia Biologica • 2021 • Том 15 / № 1 • C. 49-60 
percentage of different types of cells was determined. A special attention was paid to mononuclear cells and signs of tumor cells damage.

The chestnut saponin (BDH Chemicals Ltd, England) was used for permeabilization of tumor cells. Treatment of cells was conducted as follows. Freshly obtained ascites was diluted with a sterile solution of $0.9 \%$ sodium chloride to a cell concentration in the range of $500-800 \times 10^{3} / \mathrm{mL}$ (counted in Goryaev chamber) and $1 / 10$ volume of sterile $2 \%$ solution of chestnut saponin in saline was added (final saponin concentration $2 \mathrm{mg} / \mathrm{mL}$ ). The suspension was kept for $30 \mathrm{~min}$ at $37^{\circ} \mathrm{C}$ with occasional shaking. After cooling it to room temperature, mice were injected intraperitoneally with an aliquot of suspension containing a distinct number of cells. The suspension was stored at $4{ }^{\circ} \mathrm{C}$ no longer than 12 hrs.

Fractionation of ascitic cells population for isolation of mononuclear leukocytes from tumor-resistant mice was conducted by centrifugation in "Lymphoprep" ficoll-verografin solution (density $1.079 \mathrm{~g} / \mathrm{cm}^{3}$ ), according to recommendations of producer (Alere Technologies AS, Oslo, Norway).

Statistical analysis. The data are presented as the Mean \pm SD. The significance of difference between the compared data was analyzed by Student's $t$-test using Graph Pan Prism 6 program. Levels of significance of differences were marked with asterisks: ${ }^{*} \mathrm{P}<0.05,{ }^{* * *} \mathrm{P}<0.001$.

\section{RESULTS AND DISCUSSION}

Three schemes were tested for their efficiency in induction of resistance to tumor transplantation in mice. The first one was grounded on the treatment of tumor-bearing mice with vinblastine and, thereafter, reconvalescent animals were checked for the development of tumor resistance expressed as a complete suppression of tumor growth after re-inoculation of tumor cells. Mice were inoculated intraperitoneally with NK/Ly ascitic cells and then subjected to 2-4 intraperitoneal injections of vinblastin at a dose $1 \mu \mathrm{g} / \mathrm{g}$ of body weight. In the case of a successful treatment, reconvalescent animals were re-inoculated two weeks later with NK/Ly cells and the absence of tumor growth was considered as a development of resistance. An example of such experiment is presented in Fig. 1.

Resistance to transplantation of NK/Ly lymphoma in the presented experiment was developed after 3 injections of vinblastine at a dose of $1 \mathrm{mg} / \mathrm{kg}$ of body weight on the 6 th, 9th and 12th days after inoculation of tumor cells, followed by the removal of ascites two days after the injection of vinblastine. Similar results were obtained in about $5 \%$ of animals with lymphoma NK/Ly that survived after treatment with several injections of vinblastine starting at $24 \mathrm{~h}$ after the inoculation of tumor cells and evacuation of developed ascites. In these animals after delayed re-inoculation of viable tumor cells ascites was either not formed or was completely resorbed after a short-term growth.

Due to the fact that a prolonged remission after treatment of mice with vinblastine is relatively rare (in $5 \%$ of animals only) and unpredictable, attempts have been made to induce resistance to NK/Ly tumor by intraperitoneal inoculation of a minimal number of viable tumor cells, which will not lead to tumor growth but will initiate the immune response. However, the amount of tumor cells corresponding to these demands was not found. Inoculation of the minimal number of tumor cells $\left(15 \times 10^{3}\right.$ per mouse) led to a retarded but still progressive tumor growth, so, this scheme was abolished.

ISSN 1996-4536 (print) • ISSN 2311-0783 (on-line) • Біологічні Студії / Studia Biologica • 2021 • Том 15 / № 1 • C. 49-60 
The next undertaken scheme was the immunization of mice by intraperitoneal injections of tumor cells permeabilized with saponin. It should be noted that treatment with saponin kills cells by lysis with a minimal damage to cell morphology. Initially, 150$200 \times 10^{3}$ permeabilized cells were injected, and after $18-20$ days $400-500 \times 10^{3}$ cells of freshly prepared suspension were injected once more. After $2-3$ weeks $150-200 \times 10^{3}$ of viable NK/Ly cells were inoculated intraperitoneally to intact (control) and to immunized (vaccinated) mice. An example of experiment is presented in Fig. 2.

$\boldsymbol{A}$


Fig. 1. Dynamics of body weight of mice as an indicator of the induced resistance to tumor transplantation after inoculation of NK/Ly cells.

Designations: $\boldsymbol{A}$ - non treated mouse (control); $\boldsymbol{B}$ - mouse with resistance to inoculation of the tumor cells induced by treatment with vinblastine. The black arrow indicates the initial inoculation of tumor cells; short arrows $\downarrow$ indicate the repeated inoculations of tumor cells; red arrows $\downarrow$ show the injections of vinblastine; blue arrows $\longrightarrow$ indicate the removal of ascites in experimental mice (drainage); short blue arrows $\Downarrow$ show the washing out of cells from the abdominal cavity with saline after repeated inoculation of tumor cells

Рис. 1. Динаміка ваги тіла мишей, як показник індукованої резистентності до перевивання лімфоми NK/Ly.

Позначення: $\boldsymbol{A}$ - нелікована миша (контроль); $\boldsymbol{B}$ - миша з резистентністю до перевивання пухлини після лікування вінбластином. Чорною стрілкою позначено початкову інокуляцію пухлинних клітин; стрілками $\downarrow$ позначені повторні інокуляції пухлинних клітин; червоними стрілками $\checkmark$ показано введення вінбластину; сині стрілки $\longrightarrow$ видалення асциту у піддослідних мишей способом дренажу; короткими синіми стрілками $\downarrow$ позначено вимивання клітин із черевної порожнини фрізіологічним розчином після повторних інокуляцій пухлинних клітин

The scheme of immunization with permeabilized tumor cells appeared to be simple and effective. It provided a reproducible induction of resistance to the tumor and can serve as a model in studies of mechanisms of antitumor resistance development and its specificity. 


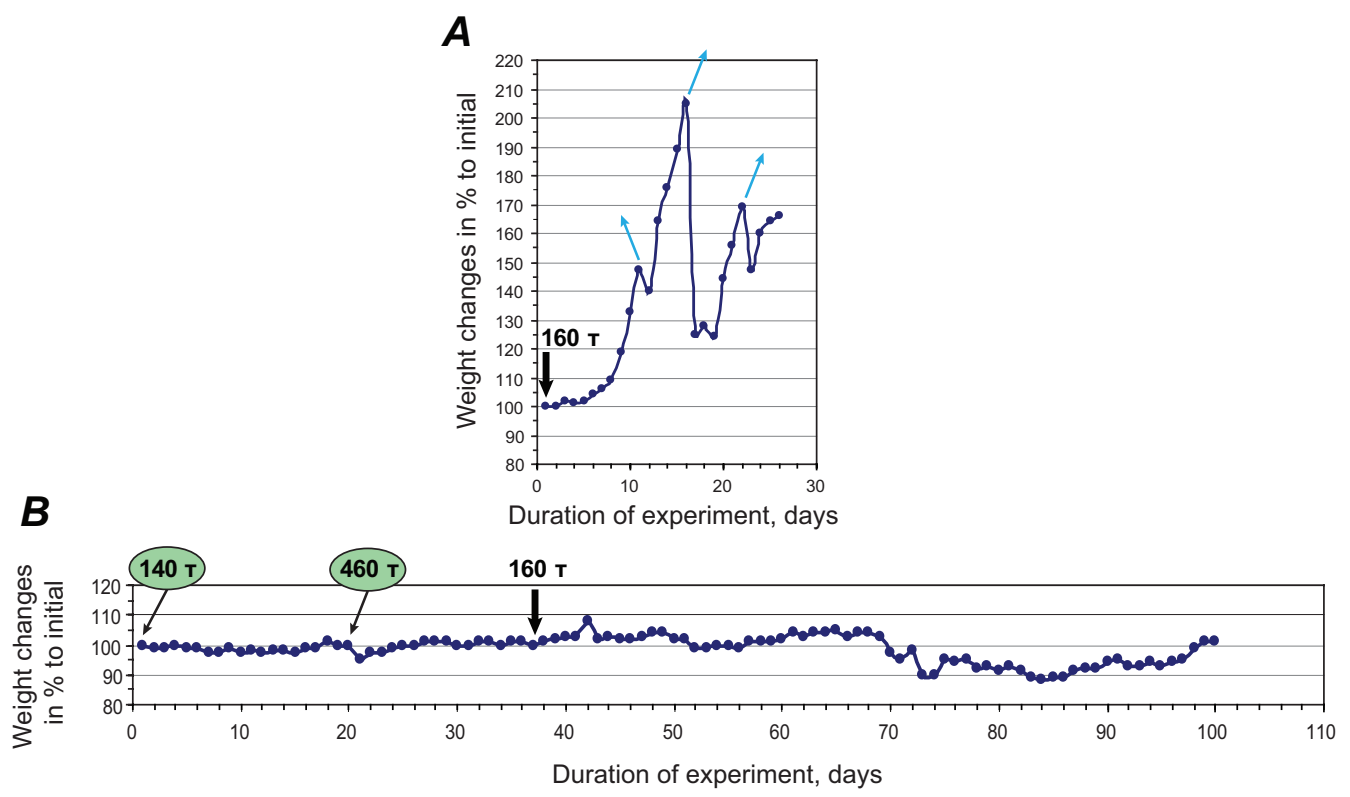

Fig. 2. Induction of resistance to NK/Ly lymphoma in mice by immunization (vaccination) with permeabilized NK/Ly cells.

Designations: $\boldsymbol{A}$ - untreated mouse; $\boldsymbol{B}$ - vaccinated mouse by prior injections of permeabilized NK/Ly cells. Arrow $P$ indicates the intra-peritoneal injection of a suspension of permeabilized NK/Ly cells (1st and 20th day, the number of cells in thousands is indicated above the arrow); arrow - inoculation of the tumor by introduction of viable NK/Ly cells (the number of cells in thousands is indicated above the arrow); arrow $\longrightarrow-$ drainage of ascites (in the control mouse only, in the vaccinated mouse tumor growth was not manifested and ascites did not develop)

Рис. 2. Індукція резистентності до лімфоми NK/Ly способом імунізації (вакцинації) мишей пермеабілізованими клітинами NK/Ly.

Позначення: $\boldsymbol{A}$ - неліковані миші; $\boldsymbol{B}$ - вакциновані миші попереднім введенням пермеабілізованих клітин NK/Ly. Стрілкою 9 позначено внутрішньочеревне введення суспензії пермеабілізованих клітин NK/Ly (1-й і 20-й дні, кількість клітин у тисячах зазначена над стрілкою); стрілка $\checkmark$ - інокуляція пухлини введенням живих клітин NK/Ly (кількість клітин у тисячах вказана над стрілкою); стрілка $\longrightarrow-$ дренаж асциту (лише у контролі, у вакцинованих мишей росту пухлини не спостерігали й асцит не утворювався)

The role of the immune response in the development of resistance of mice to the transplantation of experimental tumor NK/Ly lymphoma was studied. For this reason, the puncture of abdominal cavity with the syringe was performed in tumor resistant mice on the 2 nd or the 3rd days after provocative re-inoculation of NK/Ly cells and a small quantity of peritoneal liquid was washed out with saline for further cytomorphological investigation. The smears were stained by Romanovsky-Giemsa method and percentage of tumor cells and leukocytes was determined.

It was revealed that in tumor-resistant mice the intraperitoneal re-inoculation of tumor cells challenge the marked increase in the amount of mononuclear leukocytes in the peritoneal fluid which was approximately 4 times higher than in the ascites of control (non-treated) animals (see Table, Fig. 3B). The highest percentage of mononuclear cells was observed in the ascites obtained 2 days after the re-inoculation of tumor cells, and in 3 days or more the percentage of mononuclear leukocytes significantly 
decreased. The attachment of mononuclears to the tumor cells and a pronounced damage of the last up to their destruction was also observed (Fig. $3 C, D$ ).

Taking into account the high content of leukocytes in peritoneal fluid of tumor-resistant mice after provocative inoculation of tumor cells, we isolated leukocytes from the produced peritoneal fluid by centrifugation in density gradient of the Ficoll-verografin mixture (density $1.079 \mathrm{~g} / \mathrm{cm}^{3}$ ). A fraction of cells with typical morphology of lymphocytes was obtained (Fig. 4). However, a small number of enlarged cells which morphologically could not be clearly identified as large lymphocytes or small NK/Ly cells was also present.

\section{The content of leukocytes in ascites of non treated (control) and resistant to NK/Ly lymphoma mice after inoculation of tumor cells}

\section{Вміст лейкоцитів у асциті нелікованих (контроль) і у резистентних} щодо NK/Ly лімфоми мишей після інокуляції пухлинних клітин

\begin{tabular}{|c|c|c|}
\hline Group \# & Origin of ascites & $\begin{array}{l}\text { Percentage of mononuclear leukocytes } \\
\text { in the cell population of ascites }(M \pm S D)\end{array}$ \\
\hline 1 & Non treated (control) mice $(n=11)$ & $10.90 \pm 2.52$ \\
\hline 2 & Tumor-resistant mice $(n=8)$ & $46.54 \pm 5.90$ \\
\hline 3 & $\begin{array}{l}\text { Tumor-resistant mice on the } 2 \text { nd day } \\
\text { after inoculation of tumor cells }(n=3)\end{array}$ & $45.47 \pm 2.55$ \\
\hline 4 & $\begin{array}{l}\text { Tumor-resistant mice on the 3rd day after } \\
\text { inoculation of tumor cells }(n=3)\end{array}$ & $29.77 \pm 5.61$ \\
\hline
\end{tabular}

Comments: difference of group 1 vs group 2 : highly significant $\left.{ }^{* * *}\right), P<0.001$; difference of group 3 vs group 4 : significant $\left(^{*}\right), P=0.0115$

Примітки: різниця між групами 1 і 2: високодостовірна $\left({ }^{* * *}\right), \mathrm{P}<0,001$; різниця між групами 3 і 4: достовірна (*), $\mathrm{P}=0,0115$

Thus, the induction of resistance to transplantation of NK/Ly lymphoma in mice might be provided mainly via the mechanisms of cell immunity, in particular, by the appearance of cytotoxic lymphocytes which display harmful effect upon tumor cells.

Investigations in the field of anticancer vaccines develop very intensively due to their important practical significance. The information on principles of anticancer vaccines preparation and their application in treatment of oncological patients is presented in details in a series of excellent reviews $[10,13,16]$. In our experimental model, an acquired resistance to transplantation of lymphoma NK/Ly was achieved by preventive immunization of mice by repeated inoculation of not viable tumor cells, thus, it can be defined as vaccination. The antigen used for immunization derives from whole NK/Ly cells inactivated by permeabilization with saponin, resp., it may be classified as antigen based on tumor cell derivate [5]. The advantage of the described model is that the NK/Ly cells can be readily obtained from the ascitic fluid of a donor mouse and their treatment with saponin in aseptic conditions is not laborious. Considering the significance of this model, it is most reasonable is to use it as a source of lymphocytes which appear in a large quantity in peritoneal fluid of tumor resistant mice after provocative injection of tumor cells. The investigation of characteristics and biological, resp. cytotoxic, activity of these lymphocytes is of a significant interest. 

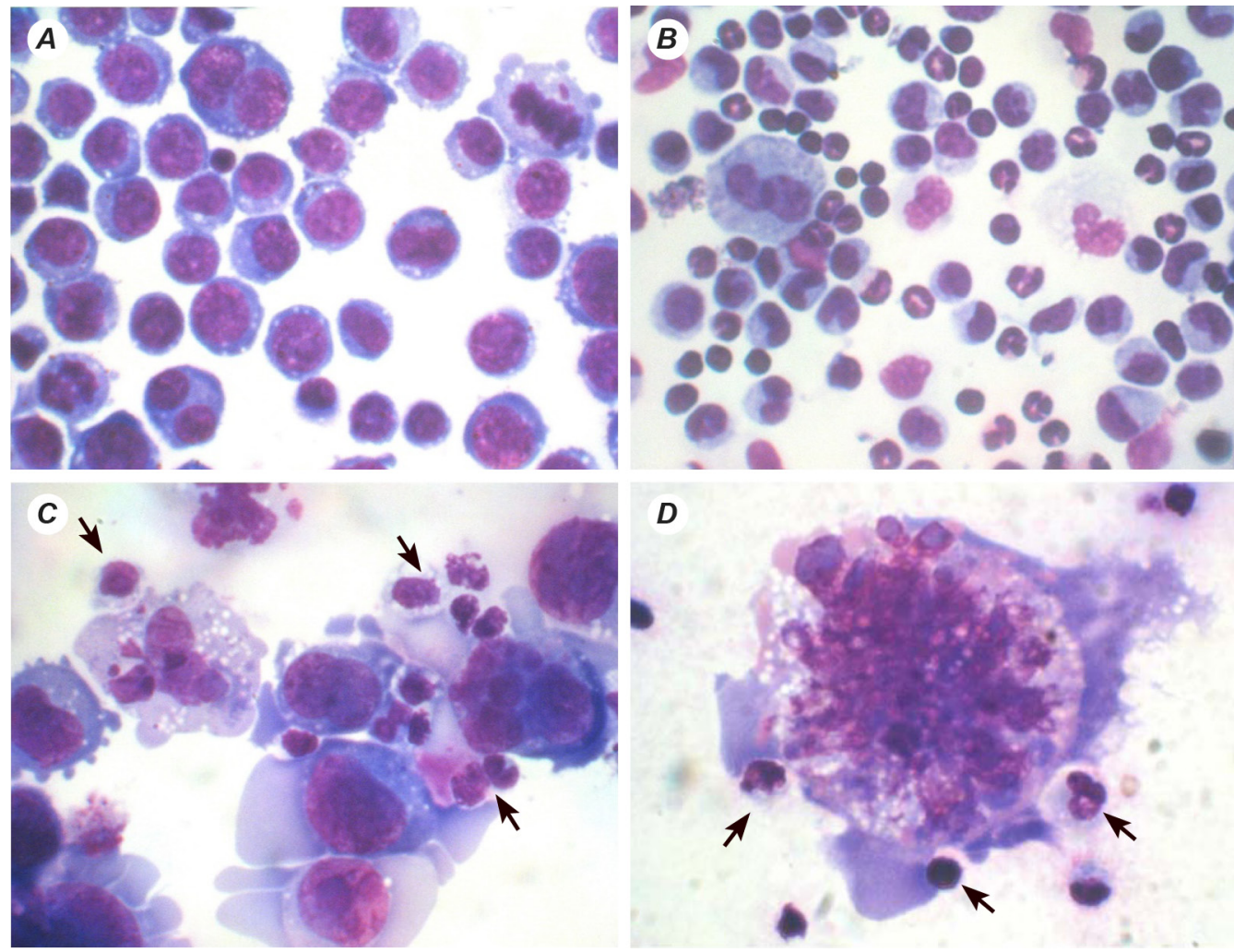

Fig. 3. The image of the cell population in ascitic fluid of the non-treated mouse (control) $(\boldsymbol{A})$ and of tumorresistent mouse after inoculation of NK/Ly cells $(\boldsymbol{B}, \boldsymbol{C}, \boldsymbol{D})$. Azure-Eosin staining, lens $40 \mathrm{x}$, eye-lens 15x. $\boldsymbol{A}$ - cell population in ascites a non-treated mouse on the 7 th day after NK/Ly cells inoculation; $\boldsymbol{B}$ - cell population in peritoneal fluid of a tumor-resistant mouse two days after NK/Ly cells inoculation. An enhenced migration of mononuclears into the peritoneal fluid is noticed; $\boldsymbol{C}$ - appearance of giant tumor cells in the mouse treated with vinblastin. Attachment of mononuclears to tumor cells and damage of their structure is observed (indicated by arrows); $\boldsymbol{D}$ - complete destruction of giant tumor cell, the adherent mononuclears are visible

Рис. 3. Клітинна популяція у асцитній рідині нелікованої миші (контроль) (A) і у пухлино-резистентної миші після інокуляції клітин NK/Ly $(\boldsymbol{B}, \boldsymbol{C}, \boldsymbol{D})$. Забарвлення Азур-Еозином, об. 40x, ок. 15x. $\boldsymbol{A}-$ клітинна популяція асциту нелікованої миші на 7-й день після інокуляції клітин NK/Ly; B - клітинна популяція перитонеальної рідини у пухлино-резистентної миші через 2 дні після інокуляції клітин NK/Ly. Помітна значна міграція мононуклеарів у перитонеальну рідину; $\boldsymbol{C}$ - утворення гігантських пухлинних клітин у мишей, лікованих вінбластином. Прикріплення мононуклеарів до пухлинних клітин і пошкодження їхньої структури (позначено стрілками); $\boldsymbol{D}$ - Повний розпад гігантської пухлинної клітини, помітно прикріплені мононуклеари (позначено стрілками)

In our experiments, mice $\mathrm{C} 57 / \mathrm{BL}$, the immunological properties of which are well characterized, were used $[2,7,19]$. They possess relatively high activity of Natural Killers and the activation of helper T cells, namely of the TH1 type secreting cytokines that are important for cell-mediated immunity. In general, the humoral immunity in C57BL/6 mice is lower comparing to the Balb/c mice. The choice of a proper animal for investigation of the mechanisms of resistance to tumor transplantation in mice is a key issue because a response to such transplantation in different animal models can vary significantly.

ISSN 1996-4536 (print) • ISSN 2311-0783 (on-line) • Біологічні Студії / Studia Biologica • 2021 • Том 15 / № 1 • C. 49-60 


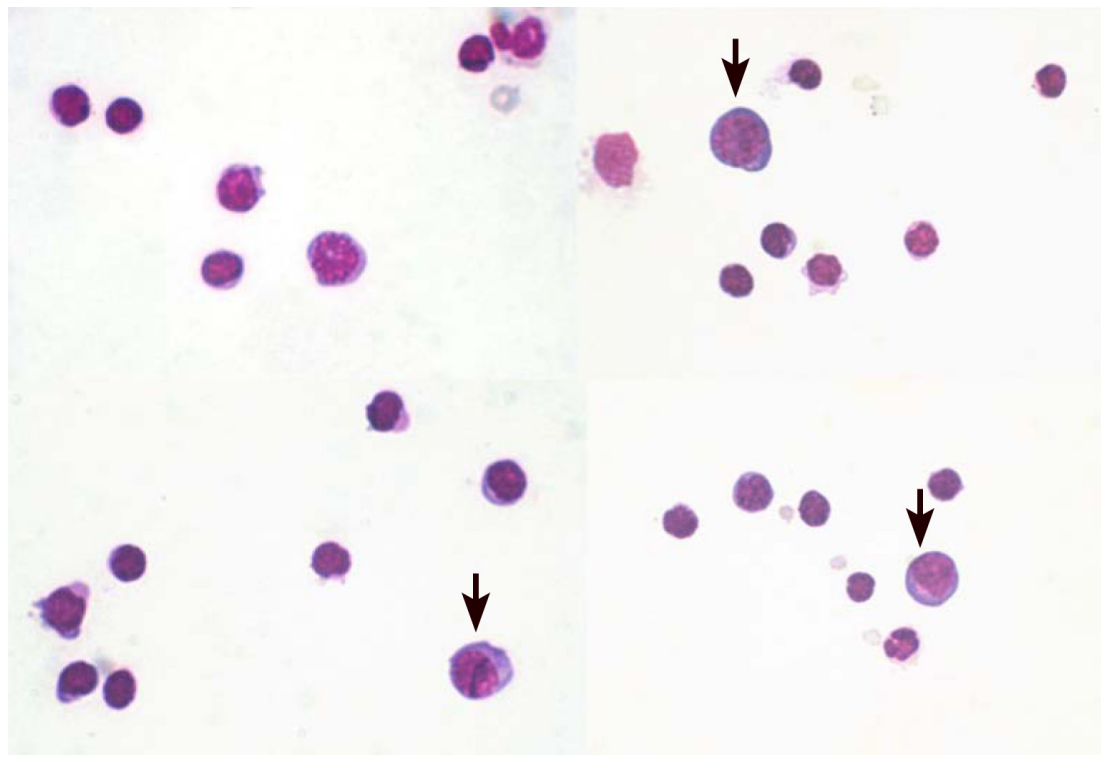

Fig. 4. Lymphoid cells, isolated from peritoneal fluid of resistant to lymphoma NK/Ly mice 48 hrs after reinoculation of tumor cells. Azure-Eosin staining, lens 40x, eye-lens 15x. Arrows indicate enlarged cells which morphologically could not be clearly identified as large lymphocytes or small NK/Ly cells

Рис. 4. Лімфоїдні клітини, ізольовані з перитонеальної рідини резистентних до лімфоми NK/Ly мишей через 48 год після ре-інокуляції пухлинних клітин. Забарвлення Азур-Еозином, об. 40х, ок. 15x. Стрілками вказано збільшені клітини, які морфологічно не можна ідентифікувати як великі лімфоцити або малі NK/Ly клітини

\section{CONCLUSIONS}

The method of induction of resistance to transplantation of experimental tumor NK/Ly by immunization of mice with tumor cells permeabilized with saponin is described. The intraperitoneal inoculation of tumor cells to the resistant mice caused a marked increase in the mononuclear leukocytes population in the perinoneal fluid, which showed a harmful effect upon tumor cells. Thus, the induction of resistance to transplantation of NK/Ly lymphoma in mice might be provided mainly via the mechanisms of cell immunity, in particular, by the appearance of cytotoxic lymphocytes specific to distinct tumor cells.

\section{COMPLIANCE WITH ETHICAL STANDARDS}

Conflict of Interest: The authors declare that the research was conducted in the absence of any commercial or financial relationships that could be construed as a potential conflict of interest.

Human Rights: This article does not contain any studies with human subjects performed by the any of the authors.

Animal studies: All institutional, national and institutional guidelines for the care and use of laboratory animals were followed. 
1. Berezhnaya N.M., Chekhun V.F. Immunology of tumor growth. Kiev: Naukova Dumka, 2005. 791 pp. (In Russian)

2. Boehm T. Design principles of adaptive immune systems. Nature Reviews Immunology, 2011; 11(5): 307-317.

Crossref $\bullet$ PubMed $\bullet$ Google Scholar

3. Bulkina V.P. Vinblastine sulfate. In: Antitumor drugs. A Refepence Book. Kiev: Naukova Dumka, 1991. P. 44-48. (In Russian)

4. Crowther M.D., Dolton G., Legut M., Caillaud M. E., Lloyd A., Attaf M., Galloway S.A.E., Rius C., Farrell C.P., Szomolay B., Ager A., Parker A.L., Fuller A., Donia M., McCluskey J., Rossjohn J., Svane I.M., Phillips J.D., Sewell A.K. Genome-wide CRISPR-Cas9 screening reveals ubiquitous $\mathrm{T}$ cell cancer targeting via the monomorphic $\mathrm{MHC}$ class I-related protein MR1. Nature Immunology, 2020; 21(2): 178-185.

Crossref $\bullet$ PubMed $\bullet$ PMC $\bullet$ Google Scholar

5. Dyukalova M.B. Anticancer vaccines based on whole tumor cells or their derivates. Russian Biotherapeutic Journal, 2012; 11(4): 3-8. (In Russian) Google Scholar

6. Gou Q., Dong C., Xu H., Khan B., Jin J., Liu Q., Shi J., Hou Y. PD-L1 degradation pathway and immunotherapy for cancer. Cell Death \& Disease, 2020; 11(11): 955.

Crossref $\bullet$ PubMed $\bullet$ PMC $\bullet$ Google Scholar

7. Kang M.J., Kim J.E., Park J.W., Choi H.J., Bae S.J., Kim K.S., Jung Y.-S., Cho J.-Y., Hwang D.Y., Song H.K. Comparison of responsiveness to cancer development and anti-cancer drug in three different C57BL/6N stocks. Laboratory Animal Research, 2019; 35: 17.

Crossref $\bullet$ PubMed $\bullet$ PMC $\bullet$ Google Scholar

8. Klein G., Sjogren H., Klein E., Helstrom K. Demonstration of resistance against methylcholantrene-induced sarcoma in primary autochtonous host. Cancer Research, 1960; 20; 1561-1572.

PubMed • Google Scholar

9. Klein G., Sjogren H., Klein E. Demonstration of host resistance against sarcoma induced by implantation of cellophane films in isologous (singeneic) recipients. Cancer Research, 1963; 23: 84-92.

PubMed • Google Scholar

10. Lebedeva E.S., Ataullakhanov R.I., Khaitov R.M. Vaccines for the treatment of malignant neoplasias. Immunologiya, 2019; 40(4): 64-76. (In Russian)

Google Scholar

11. Lilly R. Pathohistological technique and practical histochemistry. Moscow: Mir, 1969. 154-155.

(In Russian)

Google Scholar

12. Lootsik M.D., Lutsyk M.M., Stoika R.S. Nemeth-Kellner lymphoma is a valid experimental model in testing chemical agents for anti-lymphoproliferative activity. Open Journal of Blood Diseases, 2013; 3(3A): 1-6.

Crossref $\bullet$ Google Scholar

13. Mosienko V.S., Shlyakhovenko V.O. The use of vaccines in treatment of oncological disease. Klinichna immunolohiia. Alerholohiia. Infektolohiia, 2006; 1(2): 18. (In Russian)

14. Nimmagadda S. Quantifying PD-L1 Expression to Monitor Immune Checkpoint Therapy: Opportunities and Challenges. Cancers (Basel), 2020; 12(11): E3173.

Crossref $\bullet$ PubMed $\bullet$ PMC $\bullet$ Google Scholar

15. Nishimura H., Okazaki T., Tanaka Y., Nakatani K., Hara M., Matsumori A., Sasayama Sh., Mizoguchi A., Hiai H., Minato N., Honjo T. Autoimmune dilated cardiomyopathy in PD-1 receptor-deficient mice. Science, 2001; 291(5502): 319-322.

Crossref $\bullet$ PubMed $\bullet$ Google Scholar

ISSN 1996-4536 (print) • ISSN 2311-0783 (on-line) • Біологічні Студії / Studia Biologica • 2021 • Том 15 / № 1 • С. 49-60 
16. Potebnya G.P., Lisovenko G.S., Chekhun V.F. Application of cancer vaccines of IEPOR series into clinical practice of oncological establishments of Ukraine. Nauka ta Innovacii, 2009; 5(1): 62-79. (In Ukrainian)

Crossref • Google Scholar

17. Sellei C., Ekhardt S., Nemeth L. Drugs in Treatment of Tumor Diseases. Akademiai Kiado: Budapest, 1975. 21-25. (In Russian)

Google Scholar

18. Sofyina Z.P., Syrkin A.B., Goldin A., Klein A. (Eds.). Experimental evaluation of antitumor substances in USSR and USA. Moscow: Medicina, 1980. P. 71-73, 76-77. (In Russian) Google Scholar

19. Talmadge J.E., Meyers K.M., Prieur D.J., Starkey J.R. Role of natural killer cells in tumor growth and metastasis: C57BL/6 normal and beige mice23. JNCl: Journal of the National Cancer Institute, 1980; 65(5): 929-935.

Crossref $\bullet$ PubMed $\bullet$ Google Scholar

20. Wei S. C., Duffy C. R., Allison J.P. Fundamental mechanisms of immune checkpoint blockade therapy. Cancer Discovery, 2018; 8(9): 1069-1086.

Crossref • PubMed • Google Scholar

\section{ЕКСПЕРИМЕНТАЛЬНАМОДЕЛЬПІДХОДИДОВИВЧЕННЯРЕЗИСТЕНТНОСТІ ДО ПРИВИВАННЯ ПУХЛИНИ У МИШЕЙ}

\section{М. Д. Луцик, Р. С. Стойка*}

Інститут біології клітини НАН України, вул. Драгоманова, 14/16, Львів 79005, Україна

*Кореспондуючий автор e-mail: stoika@cellbiol.Iviv.ua

Вступ. Набуту резистентність до експериментальних пухлин спостерігають у тварин, які одужали від пухлини завдяки лікуванню або спонтанно і проявляють нетолерантність до ії̈ повторної інокуляції. Це явище спостерігають нечасто, однак воно становить значний науковий і медико-біологічний інтерес. У цьому випадку ми звернулися до явища резистентності у модельній пухлині мишей - лімфомі NK/Ly.

Мета цього дослідження полягала у розробці відтворюваного методу індукції резистентності до прививання вищезгаданої пухлини мишам і дослідженні механізмів її виникнення.

Методи і результати дослідження. Застосовано три схеми індукції резистентності. Перша полягала у лікуванні вінбластином миші з привитою пухлиною, після чого у тварин-реконвалесцентів визначали набуття резистентності, яка характеризувалася повним пригніченням росту пухлини після ре-інокуляції пухлинних клітин. Мишам інокулювали внутрішньочеревно асцитні клітини NK/Ly, після чого здійснювали 2-4 внутрішньочеревні ін'єкції вінбластину з розрахунку 1 мкг/г ваги тіла. Після успішного лікування мишам-реконвалесцентам проводили реінокуляцію клітин NK/Ly. Відсутність росту пухлини свідчила про виникнення резистентності. Недоліком цього підходу було низьке виліковування мишей, довготривалу ремісію спостерігали менше ніж у 5 \% мишей. Друга схема передбачала імунізацію мишей внутрішньочеревним введенням мінімальної кількості життєздатних пухлинних клітин, яка б не зумовлювала росту пухлини, але ініціювала б імунну відповідь. Однак цей підхід виявився неефективним. Мінімальна кількість введе-




пухлини. Згідно з третьою схемою, імунізацію мишей проводили внутрішньочеревними введеннями пухлинних клітин, пермеабілізованих сапоніном. Обробка сапоніном зумовлює загибель клітини з мінімальним пошкодженням структури клітини та її компонентів. Схема імунізації пермеабілізованими пухлинними клітинами виявилася простою й ефективною. Вона забезпечувала відтворювану резистентність до перевиваної пухлини і може у перспективі застосовуватися для вивчення механізмів цього явища. Проведено цитологічне дослідження пухлинних та імунокомпетентних клітин у асциті контрольних і пухлино-резистентних тварин. Виявлено, що кількість лімфоцитів у асциті пухлино-резистентних мишей була приблизно вчетверо вищою, ніж у контрольних (нерезистентних) мишей. Спостерігали руйнування пухлинних клітин прикріпленими до них мононуклеарами.

Висновок. Описано метод індукції резистентності до трансплантації експериментальної пухлини NK/Ly імунізацією мишей пухлинними клітинами, пермеабілізованими сапоніном. Внутрішньочеревна інокуляція пухлинних клітин пухлино-резистентним мишам зумовлювала значне збільшення у перитонеальній рідині популяції мононуклеарних лейкоцитів, які спричиняли пошкодження пухлинних клітин. Це свідчить, що виникнення резистентності до перевивання лімфоми NK/Ly мишам визначається головно механізмами клітинного імунітету, зокрема, утворенням цитотоксичних лімфоцитів, специфрічних до пухлинних клітин.

Ключові слова: лімфома NK/Ly, миші, перевивання пухлин, резистентність

Revision / Доопрацьовано 25 February, 2021
Accepted / Прийнято 17 March, 2021
Published / Опубліковано 31 March, 2021

ISSN 1996-4536 (print) • ISSN 2311-0783 (on-line) • Біологічні Студії / Studia Biologica • 2021 • Том 15 / № 1 • С. 49-60 